\title{
The accumulation of SA- and JA-signaling pathways in the response of Glycine max cv. "Nam Dan” to infestation by Aphis craccivora
}

\author{
Ngoc Toan Tran ${ }^{1}$, Thi Thanh Huyen Tran², Ngoc Dai Do ${ }^{3}$, Van Chung Mai ${ }^{4 *}$ \\ ${ }^{1}$ Department of Plant Sciences, Vinh University, Str. Le Duan 182, Vinh City, Nghe Ane, Vietnam \\ ${ }^{2}$ Department of Plant Physiology, Hanoi National University of Education, Str. Xuan Thuy 136, Cau Giay District, \\ Hanoi, Vietnam \\ ${ }^{3}$ Faculty of Agriculture, Forestry \& Fishery, Nghe An College of Economics, Str. Ly Tu Trong 51, Vinh City, \\ Nghe An, Vietnam \\ ${ }^{4}$ Department of Plant Physiology, Vinh University, Le Duan 182, Vinh City, Nghe An, Vietnam
}

Vol. 57, No. 4: 321-330, 2017

DOI: 10.1515/jppr-2017-0043

Received: July 21, 2017

Accepted: October 23, 2017

*Corresponding address:

chungmv@vinhuni.edu.vn

\begin{abstract}
Phytohormones function as signal molecules that regulate physiological processes to protect plants from environmental stresses, including aphids' attack. We studied the pattern within the defense mechanisms of soybean [Glycine max (L.) Merr. cv. "Nam Dan"] regarding the signaling pathways of salicylic acid (SA), and jasmonic acid (JA) in response to cowpea aphid (Aphis craccivora Koch). With infestation by cowpea aphid, SA was the first to accumulate and reached high levels 24 hours post-infestation (hpi). An accumulation of SA in the early response of soybean probably triggers inducible specific defense reactions. Following SA, JA was later induced and continuously increased to high levels 96 hpi. An accumulation of JA in the later response may be a critical step in the signaling of the downstream defense cascade. In addition, phenylalanine ammonia-lyase (PAL, EC 4.3.1.24) and benzoic acid 2-hydroylase (BA2H), enzymes involved in the biosynthesis of SA, and lipoxygenase (LOX, EC 1.13.11.12), an important enzyme in the JA biosynthesis pathway, were also induced by cowpea aphid. The changes in the enzymatic activity of PAL, BA2H and LOX, and expression of gene encoding PAL were closely associated with the accumulation of endogenous SA and JA, respectively. The variations in the levels of these defense-related compounds were strongly connected with density and the duration of cowpea aphid infestation. Different accumulations of SA- and JA-signaling pathways may contribute to a coordinated regulation leading to the formation of resistant lines in the defense mechanisms of G. max cv. "Nam Dan" against A. craccivora.
\end{abstract}

Key words: Aphis craccivora, Glycine max, defense response, jasmonic acid, phytohormones, salicylic acid

\section{Introduction}

Phytohormones are bioactive endogenous molecules that are important in regulating developmental processes and signaling networks involved in plant defense mechanisms. The most well-known class of phytohormonal signals in plant defense response to insects is jasmonic acid (JA). The enhancement of JA and its derivatives such as methyl jasmonate (MeJA), 12-oxo-phytodienoic acid (OPDA) are known to trigger defense mechanisms against aphids in various crops, e.g., Arabidopsis, tobacco, wheat, Barrel clover, tomato, sorghum, etc., with different expression levels (Morkunas et al. 2011). Jasmonic acid is also known as a signal molecule in defense mechanisms to protect plants from wounding, in which activation of JA-mediated defense often contributes to limited tissue damage from feeding activities (Halitschke and Baldwin 2005). 
Lipoxygenase (LOX), the key enzyme in the JA biosynthesis pathway, is also induced in host plants, and functions as an important component of the plant response system to insect attack (Moran and Thompson 2001; Mai et al. 2014). Microarray analyses provided evidence of the induced defensive role for JA signaling for wounds and JA inducible defense genes in some plant-aphid interactions (Martinez de Ilarduya et al. 2003).

Salicylic acid (SA) is mainly known to be involved in both locally expressed basal resistance and systemic acquired resistance (SAR) in plants to pathogens. The role of SA in response to aphids has been observed in some plant species, in which, induction of SA involved the resistance of plants against aphids (Mohase and van der Westhuizen 2002). Markers of resistance response (antioxidant enzymes such as catalase, peroxidase, etc.) in the resistant variety were seen by higher expression than in susceptible plants. At the transcriptional level, a number of SA-defense-related genes participated in the plant defense mechanisms against aphids. For example, expression of gene encoding phenylalanine ammonialyase (PAL - an enzyme involved in the biosynthesis of SA) and pathogenesis-related protein (PRs) such as PR5, and $P R 10$ were activated by infestation by the bluegreen aphid in barrel clover plant (Gao et al. 2007).

The SA- and JA-signaling pathways have been known to act in the antagonistic cross-talk, in which the induction of the less efficient SA signaling-based responses is able to suppress effective JA defenses, and vice versa. This could be a decoy strategy, rerouting plant response towards an inefficient defense against feeding aphids. In the light of cross-talk between the SA and JA-signaling pathways, Kuśnierczyk et al. (2008) elucidated that aphids can manipulate plant-induced resistance and are able to suppress effective JA defenses by the induction of the less efficient SA signalingbased responses. Moreover, plant defense mechanisms regarding SA and JA are closely associated with density and/or duration of aphid infestation (Donovan et al. 2013; Kroes et al. 2015; Stewart et al. 2016).

Cowpea aphid (Aphis craccivora Koch) is one of the most destructive aphid species of the "Nam Dan" soybean [Glycine max (L.) Merr.] cultivar which is a valuable crop in the agricultural production in Nghe An province (Vietnam). Information in the available literature regarding the interaction between G. max cv. "Nam Dan" and A. craccivora is still limited (Mai et al. 2016). The first aim of this study was to determine the effect of various numbers of aphids on the accumulation of endogenous SA and JA in G. $\max \mathrm{cv}$. "Nam Dan". Also the effect of different time intervals was observed. The second aim was to determine the changes in the activity of the following enzymes: phenylalanine ammonia-lyase (PAL, EC 4.3.1.24) and benzoic acid 2-hydroxylase (BA2H) in the SA biosynthetic pathway, and lipoxygenase (LOX, EC 1.13.11.12), an important enzyme in the biosynthesis of JA under aphid infestation. Furthermore, changes in expression of gene encoding PAL and the isoenzymatic spectrum of LOX were also investigated.

\section{Materials and Methods}

\section{Plant}

The plant used in this study was the cultivar "Nam Dan" of soybean (G. max). Soybean seeds were obtained from the Nghe An seed center (Vietnam). The surface-sterilized seeds were imbibed in the incubator at $23^{\circ} \mathrm{C}$ for $48 \mathrm{~h}$, then cultured in plastic pots $20 \mathrm{~cm}$ in diameter containing Hoagland medium and placed in a phytotron at $23 \pm 2^{\circ} \mathrm{C}, 70-75 \%$ relative humidity, light intensity of $110-130 \mu \mathrm{M} \cdot \mathrm{m}^{-2} \cdot \mathrm{s}^{-1}$ and 14 light : 10 dark hours. Soybean at the V3 stage (with the first two trifoliate leaves fully developed, and the third trifoliate leaf unrolled) were used as materials for aphid-infested treatment.

\section{Aphid}

The aphid species used in the infestation experiments was cowpea aphid (A. craccivora), which was supplied by the Department of Applied Entomology (Vietnam Academy of Science and Technology). Virus free individuals were cultured on their host, G. max, in a phytotron at $23 \pm 2^{\circ} \mathrm{C}, 70-75 \%$ relative humidity, light intensity of $110-130 \mu \mathrm{M} \cdot \mathrm{m}^{-2} \cdot \mathrm{s}^{-1}$ and 14 light : 10 dark hours (Mai et al. 2016).

\section{Infestation experiment}

Each soybean plant was treated separately with 10 , 20 or 30 wingless adults of $A$. craccivora. The wingless cowpea aphid adults were selected and transferred carefully to soybean leaves with a fine paintbrush. The newly produced nymphs were daily removed to prevent density-dependent effects on aphid performance; therefore, the number of wingless adults of A. craccivora was constant in each infestation experiment. The control group included soybean plants without aphid treating. The control and aphid-infested variants were separately put in glass boxes $(50 \times 50 \times 50 \mathrm{~cm})$, covered by nylon gauze and placed in a phytotron where temperature, relative humidity, light intensity and period were controlled. The experiment was repeated at three different time points under the same conditions.

\section{The analytical materials}

Fresh leaves in control and aphid-infested plants were carefully collected at $0,24,48,72$ and 96 hours post-infestation (hpi). All aphid individuals were removed; 
leaves were accurately weighed, and immediately frozen in liquid nitrogen for subsequent analyses.

\section{Salicylate measurement}

Free salicylic acid (SA) was extracted and quantified following the high-performance liquid chromatography (HPLC) method described by Yalpani et al. (1993) with minor modifications. $0.50 \mathrm{~g}$ frozen leaves were ground in liquid nitrogen to a fine powder, then extracted twice with $90 \%$ methanol, stirred vigorously and centrifuged again at $12,000 \times g$ for $10 \mathrm{~min}$ at $4^{\circ} \mathrm{C}$. After centrifugation, the supernatant was evaporated to dryness under a stream of nitrogen, then extracted three times with the extractive mixtures of ethyl acetate : cyclopentane : isopropanol $(100: 99: 1, \mathrm{v} / \mathrm{v} / \mathrm{v})$.

After evaporating the solvent, the dry residue was dissolved in a mobile phase $(0.2 \mathrm{M}$ acetate buffer, pH 5.0 and 0.5 mM EDTA) and analysed in the HPLC system with a WATERS Company chromatograph (Milford, Ma, USA) composed of 2699 Separation Module Alliance and 2475 Multi- $\lambda$ Fluorescence Detector. Chromatographic separation was on a Spherisorb ODS2 WATERS Company column $(3 \mu \mathrm{m}, 4.6 \times 10 \mathrm{~mm})$. Detection parameters were at $295 \mathrm{~nm}$ for excitation and $405 \mathrm{~nm}$ for emission. The SA content was calculated following the SA standard (Sigma-Aldrich, USA) and expressed as nanograms per gram of fresh weight material (ng $\left.\cdot \mathrm{g}^{-1} \mathrm{FW}\right)$.

\section{Jasmonates measurement}

The analyses of jasmonic acid (JA) and its methyl ester (MeJA) were carried out following the GC-MS methods (Fan et al. 1998) with modifications. Soybean leaves were shock-frozen in liquid nitrogen and stored at $-80^{\circ} \mathrm{C}$. One $\mathrm{g}$ of each sample was ground to a fine powder and extracted three times with a total of $60 \mathrm{ml} \mathrm{80 \%} \mathrm{(v/v)} \mathrm{methanol.} \mathrm{The} \mathrm{internal} \mathrm{standards}$ including $200 \mathrm{ng}$ deuterium-labeled jasmonic- $\mathrm{d}_{5}$ acid $\left(\mathrm{d}_{5}-\mathrm{JA}\right.$, Clearsynth, USA) and $200 \mathrm{ng}$ deuterium-labeled methyl- $\mathrm{d}_{2}$-jasmonate ( $\mathrm{d}_{2}$-MeJA, Sigma-Aldrich, USA) were added to the homogenized mixture. The homogenate was filtered, centrifuged at $10,000 \times g$ at $4^{\circ} \mathrm{C}$ for $10 \mathrm{~min}$, then acidified to $\mathrm{pH} 2.0$ with $7 \mathrm{M} \mathrm{HCl}$ and centrifuged again. After being partitioned three times against chloroform the supernatant was dried. The residue was dissolved in $3 \mathrm{ml} n$-hexane and applied to a silica gel solid-phase extraction column (Backer-bound SPE silica gel, $500 \mathrm{mg}, 3 \mathrm{ml}$; J.T. Backer, Philipsburg, NJ, USA). The column was washed with $5 \mathrm{ml} n$-hexane and then eluted with $6 \mathrm{ml}$ mixture of $n$-hexane : diethyl ether $(2: 1, \mathrm{v} / \mathrm{v})$ with $0.5 \%(\mathrm{v} / \mathrm{v})$ acetic acid. The eluate was evaporated and dissolved in $100 \mu \mathrm{l}$ of $20 \%$ methanol and chromatographed for $20 \mathrm{~min}$, flow rate $1.0 \mathrm{ml} \cdot \mathrm{min}^{-1}$, at $22^{\circ} \mathrm{C}$. The fractions were collected at the retention times of $12.50-13.80 \mathrm{~min}$ for JA and 18.50-19.60 min for MeJA, and then fully evaporated and methylated with diazomethane, then dissolved in $50 \mu \mathrm{l}$ of methanol prior to an analysis by GC-MS-SIM (Auto-System XL coupled to a Turbo Mass, Perkin Elmer) using a DB-5 column $(30 \mathrm{~m} \times 0.25 \mathrm{~mm}$, $0.25 \mu \mathrm{m}$ phase thickness, Agilent Technologies). The GC temperature program was $80^{\circ} \mathrm{C}$ for $1 \mathrm{~min}, 80-160^{\circ} \mathrm{C}$ at $10^{\circ} \mathrm{C} \cdot \mathrm{min}^{-1}, 160-230^{\circ} \mathrm{C}$ at $5^{\circ} \mathrm{C} \cdot \mathrm{min}^{-1}$, flow rate $1 \mathrm{ml} \cdot \mathrm{min}^{-1}$, injection port $250^{\circ} \mathrm{C}$, electron potential $70 \mathrm{eV}$. GC/MS-selected ion monitoring was performed by monitoring $\mathrm{m} / \mathrm{z} 156,161,193,198,224,226$ and 229. The dwell time for all ions was $100 \mathrm{~ms}$. The levels of JA and MeJA in the extract were determined from the ratio of peak area, calculated following JA and MeJA standards, and expressed as nanograms per gram of fresh weight material $\left(\mathrm{ng} \cdot \mathrm{g}^{-1} \mathrm{FW}\right)$.

\section{Phenylalanine ammonia-lyase assay}

Phenylalanine ammonia-lyase (PAL, EC 4.3.1.24) activity was determined using the spectrophotometric method (Cahill and McComb 1992). $0.50 \mathrm{~g}$ of frozen leaves were homogenized at $4^{\circ} \mathrm{C}$ in $4 \mathrm{ml}$ of $100 \mathrm{mM}$ Tris-HCl buffer ( $\mathrm{pH}$ 8.9), $5 \mathrm{mM} \beta$-mercaptoethanol nd $0.050 \mathrm{~g}$ polyvinyl pyrrolidone (PVP). The homogenate was then centrifuged at $12,000 \times g$ for $20 \mathrm{~min}$ at $4^{\circ} \mathrm{C}$ to get the supernatant used for enzyme analysis. $1.5 \mathrm{ml}$ of the reaction mixtures contained $0.50 \mathrm{ml}$ of borate buffer $20 \mathrm{mM}, \mathrm{pH} 8.9,0.50 \mathrm{ml}$ of $L$-phenylalanine $10 \mathrm{mM}$, and $0.50 \mathrm{ml}$ enzyme extract. A sample without $L$-phenylalanine was used as a blank. After incubation at $30^{\circ} \mathrm{C}$ for $24 \mathrm{~h}$, the substrate was added and the reaction was stopped with $1.5 \mathrm{ml}$ of $2 \mathrm{~N} \mathrm{HCl}$. The activity of PAL was measured by the change of absorbance at $290 \mathrm{~nm}$ using the UV-Vis CARY 60 spectrophotometer (Agilent, USA) system. Data were analyzed by using the UV-Win 5.0 application software. The activity of PAL was expressed as micromol trans-cinnamic acid per mg protein per hour ( $\mu \mathrm{M}$ trans-cinnamic acid . . $\mathrm{mg}^{-1}$ protein $\left.\cdot \mathrm{h}^{-1}\right)$.

\section{Benzoic acid 2-hydroxylase assay}

Benzoic acid 2-hydroxylase (BA2H) was measured by using the HPLC method according to León et al. (1995) with minor modifications. $0.50 \mathrm{~g}$ of frozen leaves was ground, and the resulting fine powder was suspended in $2 \mathrm{ml}$ of extractive buffer [20 mM HEPES buffer, $\mathrm{pH} 7.0$, containing $12.5 \mathrm{mM}$ 2-mercaptoethanol, $10 \mathrm{mM}$ sorbitol, 1\% PVP, and $0.1 \mathrm{mM}$ phenylmethylsulfonyl fluoride (PMSF)]. The suspension was vortexed and then centrifuged at $12,000 \times g$ for $15 \mathrm{~min}$ at $4^{\circ} \mathrm{C}$. All extraction procedures were carried out at $4^{\circ} \mathrm{C}$. The supernatant was used for enzyme assays.

A final volume of $0.50 \mathrm{ml}$ reaction mixture contained $20 \mathrm{mM}$ of HEPES buffer (pH 7.0), $1 \mu \mathrm{M}$ of benzoic acid 
(BA), $1 \mu \mathrm{M}$ of $\mathrm{NAD}(\mathrm{P}) \mathrm{H}$, extractive buffer and enzyme extract. The reaction mixture was incubated at $30^{\circ} \mathrm{C}$ in a water bath for $30 \mathrm{~min}$, and thereafter, $250 \mu \mathrm{l}$ of $15 \%$ trichloroacetic acid (TCA) was added to stop the reaction. After vortex and centrifuging at $12,000 \times g$ for $10 \mathrm{~min}$ at $4^{\circ} \mathrm{C}$, the supernatant was partitioned three times with $0.50 \mathrm{ml}$ of the extractive organic mixtures of ethyl acetate : cyclopentane : isopropanol (100: $99: 1$, $\mathrm{v} / \mathrm{v} / \mathrm{v})$. The extract was transferred to a $2-\mathrm{ml}$ glass and evaporated to dryness under a stream of nitrogen. The sample was dissolved in $250 \mu \mathrm{l}$ mobile phase immediately before use. Whole was thoroughly mixed, then transferred to Eppendorf tubes and centrifuged at $15,000 \times g$ for 2 min. $200 \mu \mathrm{l}$ extract of each sample was placed in a glass vial fitted with a rubberized Teflon-sept and placed in the chamber of an auto sampler chamber. The injection volume was constant $(10 \mu \mathrm{l})$. The SA concentration was analyzed by the HPLC method (as described above). The activity of BA2H was expressed as nanograms of SA obtained as a reaction's product during one hour for the enzyme extracted from $1 \mathrm{mg}$ of protein (ng SA $\cdot \mathrm{h}^{-1} \cdot \mathrm{mg}^{-1}$ protein).

\section{Semi-quantitative reverse transcription- -polymerase chain reaction (semiquantitative RT-PCR) of PAL gene}

Total RNA was extracted and isolated from soybean leaves by trizol/chloroform extraction. $0.25 \mathrm{~g}$ of frozen sample were ground in a chilled mortar and the resulting fine powder then transferred to $1.5 \mathrm{ml}$ Eppendorf tubes. Firstly, $1 \mathrm{ml}$ trizol (Invitrogen) solution was added to each tube and kept at an ambient temperature for $3 \mathrm{~min}$, then $0.2 \mathrm{ml}$ chloroform and vigorously shaken for $15 \mathrm{~s}$. After $15 \mathrm{~min}$ at $37^{\circ} \mathrm{C}$, the mixture was centrifuged at $8,000 \times g$ for $15 \mathrm{~min}$ at $4^{\circ} \mathrm{C} .500 \mu \mathrm{l}$ supernatant and $0.5 \mathrm{ml}$ isopropanol were added and incubated at $-20^{\circ} \mathrm{C}$ for $30 \mathrm{~min}$, then centrifuged at $14,000 \times g$ for $10 \mathrm{~min}$ at $4^{\circ} \mathrm{C}$ to select residue was then immersed in $70 \% \mathrm{v} / \mathrm{v}$ diethyl pyrocarbonate (DEPC), centrifuged again at $14,000 \times g$ for $5 \mathrm{~min}$ at $4^{\circ} \mathrm{C}$, and subsequently dried at $37^{\circ} \mathrm{C}$ for $72-96 \mathrm{~h}$. The residue was dissolved in $30 \mu \mathrm{l} \mathrm{DEPC}$ to obtain the RNA extracted solution. A final volume of $1 \mu \mathrm{l}$ extraction was used in quantitative analysis of total RNA in NanoDrop Lite Spectrophotometer (Thermo Scientific).

DNA biosynthesis was carried out in a final volume of $12 \mu \mathrm{l}$ containing $1 \mu \mathrm{l}$ RNA extract, $1 \mu \mathrm{l}$ primer (hex$\mathrm{am})$ and deionized water and was started by mixing at $65^{\circ} \mathrm{C}$ for $5 \mathrm{~min}$. After that, $4 \mu \mathrm{l}$ of $5 \times \mathrm{RT}$ buffer $(250 \mathrm{mM}$ Tris- $\mathrm{HCl}, \mathrm{pH} 8.3,250 \mathrm{mM} \mathrm{KCl}, 2.5 \mathrm{mM}$ spermidine, $50 \mathrm{mM} \mathrm{MgCl}, 50 \mathrm{mM}$ DTT), $4 \mu \mathrm{l}$ of $10 \mu \mathrm{M}$ of deoxynucleotides (dNTPs), $1 \mu \mathrm{l}$ of 20 units of RNase inhibitor (Boehringer Mannheim), and $1 \mu \mathrm{l}$ of 200 units of Moloney Murine Leukemia Virus (M-MLV) reverse transcriptase
(Promega) was added. Incubation was prolonged at $4^{\circ} \mathrm{C}$ for $1 \mathrm{~h}$ and $2 \mu \mathrm{l}$ of the single strand cDNA was used for PCR amplification. Polymerase chain reaction reaction was performed in a volume of $20 \mu \mathrm{l}$ using $10 \mu \mathrm{l}$ Master mix 2x (Promega), $0.5 \mu \mathrm{l}$ specific primers (10 pmol), $2 \mu \mathrm{l}$ cDNA and the deionized water. The applied program for cDNA biosynthesis applied in the PCR PTC-100 thermal cycler (MJ Research) was operated at $25^{\circ} \mathrm{C}$ for $5 \mathrm{~min}$ followed by $42^{\circ} \mathrm{C}$ for $60 \mathrm{~min}$ and ended at $70^{\circ} \mathrm{C}$ for $5 \mathrm{~min}$. Genomic DNA Sample Preparation Kit from Revert Aid (Thermo Scientific) was used.

Primers for amplification were designed on the basis of the cDNA sequences encoding gene of PAL from soybean leaves such as:

- the forward primer for $P A L$ :

5'-CGGTTCATTTTGCTTGTCCAC-3';

- the reverse primer for $P A L$ :

5'-CTGAGCGATGGTGAGAGTC-3'.

The amplicon was 166 base pairs (bp).

The following actin primers were used as positive controls:

- the forward primer for actin:

5’-CGCTGGTCGTGATCTAACTG-3';

- the reverse primer for actin:

5'-GCTCATGGCTTTTCTCAACTG -3'.

The amplicon was $185 \mathrm{bp}$.

The thermal cycling conditions were $94^{\circ} \mathrm{C}$ for $4 \mathrm{~min}$ followed by 25 cycles $\left(95^{\circ} \mathrm{C}\right.$ for $1 \mathrm{~min}, 48^{\circ} \mathrm{C}$ for $3 \mathrm{~min}$, and $72^{\circ} \mathrm{C}$ for $30 \mathrm{~s}$ ), and $72^{\circ} \mathrm{C}$ for $7 \mathrm{~min}$, then kept at $4^{\circ} \mathrm{C}$.

The RNA was electrophoresed in $2 \%$ agarose gels and blotted onto Hybond $\mathrm{N}$ membranes following standard procedures. Hybridization with the specific probes was carried out at $42^{\circ} \mathrm{C}$ in an Ethidium bromide solution.

\section{Lipoxygenase assay}

The activity of lipoxygenase (LOX, EC 1.13.11.12) was determined following the spectrophotometric method (Sekhar and Reddy 1982). $0.50 \mathrm{~g}$ frozen leaves were ground with $3 \mathrm{ml} 100 \mathrm{mM}$ phosphate buffer ( $\mathrm{pH} 7.0$ ). The homogenate was then centrifuged at $12,000 \times g$ for $30 \mathrm{~min}$ at $4^{\circ} \mathrm{C}$. The supernatant was used as enzymatic extract for LOX activity assay. A linoleic acid solution was prepared at a concentration of $10 \mathrm{mM}$. The substrate solution consisted of $100 \mathrm{mM}$ borate buffer ( $\mathrm{pH} 10.0$ ), Tween 20, and $10 \mathrm{mM}$ linoleic acid. The reaction mixture consisted of $2.9 \mathrm{ml}$ borate buffer, $50 \mu \mathrm{l}$ substrate, and $50 \mu \mathrm{l}$ enzymatic extract. The activity of LOX was determined from the increase in optical density values at $234 \mathrm{~nm}$ wavelength in the $\mathrm{UV}$-Vis CARY 60 spectrophotometer (Agilent, USA) system. The results were expressed as nanokatal of LOX activity per $\mathrm{mg}$ protein per minute $\left(\mathrm{nkat} \cdot \mathrm{mg}^{-1}\right.$ protein $\cdot \mathrm{min}^{-1}$ ). 


\section{Determination of lipoxygenase isoenzymes}

$0.50 \mathrm{~g}$ frozen leaves were homogenized and extracted in $5 \mathrm{ml}$ of $0.2 \mathrm{M}$ borate buffer ( $\mathrm{pH} 7.0$ ) and centrifuged at $12,000 \times g$ for $15 \mathrm{~min}$ at $4^{\circ} \mathrm{C}$. The solution of proteins isolated with the extracted borate buffer was electrophoresed in $7 \%$ polyacrylamide gel containing ampholytes ( $\mathrm{pH} 3.5-10.0$ ). Lipoxygenase isoenzyme was visualized by staining with $1 \% \mathrm{~N}, \mathrm{~N}$-dimethyl-p-phenylene diamine (Rucińska and Gwóźdź 2005).

\section{Determination of protein}

In all the enzyme preparations, the protein in soybean seedlings' leaves was determined following the method of Bradford (1976) using bovine serum albumin (Sigma-Aldrich) as a standard.

\section{Statistical analysis}

All determinations were performed in three independent experiments. Analysis of variance (ANOVA) was applied to determine if means from the independent experiments within a given variant were significant at the level $p<0.05$. Data shown in the figures are means of each variant and standard errors (SE), using asterisks to present significant differences.

\section{Results}

\section{Accumulation of salicylates in soybean leaves after aphid infestation}

Infestation by $A$. craccivora induced an accumulation of free SA in G. max cv. "Nam Dan" leaves. Salicylic acid was accumulated early, $24 \mathrm{hpi}$, and maintained

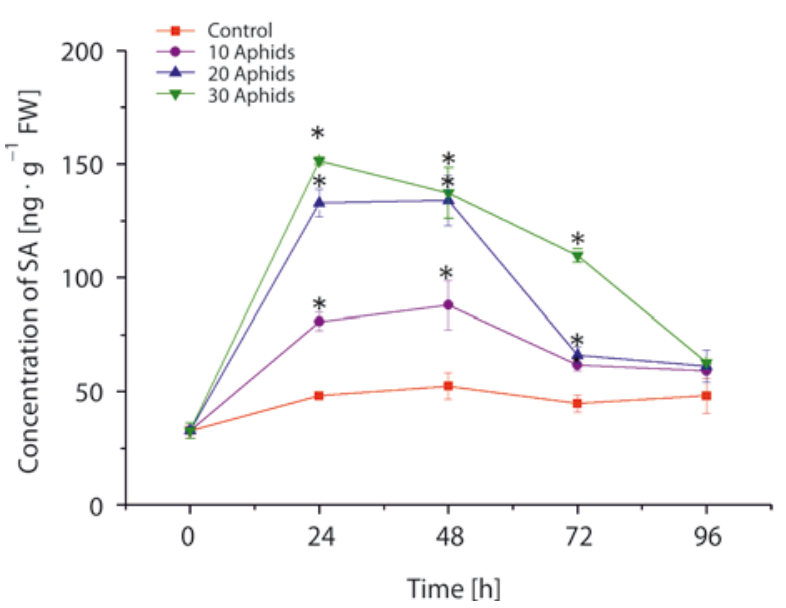

Fig. 1. Effect of Aphis craccivora infestation on salicylate content in leaves of Glycine max cv. "Nam Dan". Values are means $\pm \mathrm{SE}$ of three independent experiments. $\left(^{*}\right)$ in figure shown the significant difference between the experimental variants and control at level $p<0.05$ high levels until $48 \mathrm{hpi}$ and then strongly dropped within 72-96 hpi. This phytohormone in the control plants maintained consistently lower levels (Fig. 1). The highest content of SA obtained $151.38 \mathrm{ng} \cdot \mathrm{g}^{-1} \mathrm{FW}$ was in 30 -aphids infested leaves at $24 \mathrm{hpi}$. It was 4.62 -fold higher than at the beginning ( $\left.32.76 \mathrm{ng} \cdot \mathrm{g}^{-1} \mathrm{FW}\right)$ and 3.14 -fold higher than in control plants $\left(48.08 \mathrm{ng} \cdot \mathrm{g}^{-1} \mathrm{FW}\right)$. There was a close correlation between the content of accumulated SA with the density of cowpea aphid infestation. ANOVA results showed that significant differences between the concentration of SA in aphid-infested leaves and control were recorded within 24-72 hpi.

\section{Accumulation of jasmonates in soybean leaves after aphid infestation}

The gas chromatography-mass spectrometry (GC-MS) analytical results showed that levels of MeJA were very low (intensity of investigated ions was very small) in leaves of G. max cv. "Nam Dan" plants. This crop mainly contained JA, so we assessed the total jasmonate content (JA and MeJA) in all samples and the symbol JA was used. This phytohormone in the aphid-infested variants increased from the beginning up to $96 \mathrm{hpi}$ (Fig. 2). The highest concentration of JA (493.68 $\mathrm{ng} \cdot \mathrm{g}^{-1}$ FW) was recorded in leaves infested by 30 aphids at $72 \mathrm{hpi}$, and was 2.92-fold higher than the control $\left(234.73 \mathrm{ng} \cdot \mathrm{g}^{-1} \mathrm{FW}\right)$. The content of JA in aphid-infested leaves was always significantly different than in the control plants $(\mathrm{p}<0.05)$. Furthermore, the JA content was proportional with the numbers of cowpea aphid attacking within 48-96 hpi; a higher number of cowpea aphid attacking caused a greater increase in JA content, and vice versa. This correlation suggested that the accumulated content of JA in soybean leaves was closely related to duration and density of cowpea aphid infestation.

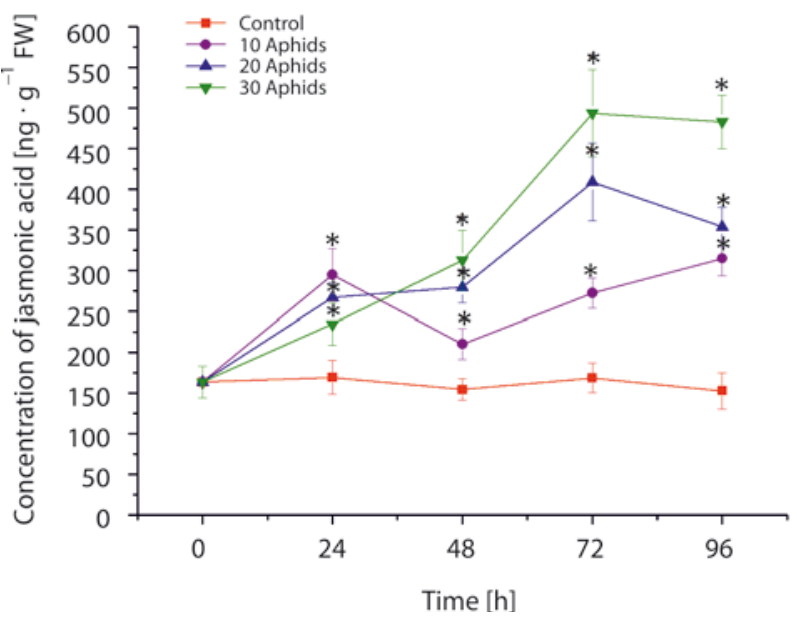

Fig. 2. Effect of Aphis craccivora infestation on jasmonates content in leaves of Glycine max cv. "Nam Dan". Values are means $\pm \mathrm{SE}$ of three independent experiments. $\left({ }^{*}\right)$ in figure shown the significant difference between the experimental variants and control at level $p<0.05$ 


\section{Activity of PAL and expression of PAL gene in soybean leaves after aphid infestation}

The activity of enzyme phenylalanine ammonia-lyase (PAL, EC 4.3.1.24) was strongly induced in G. max leaves after infestation by different numbers of $A$. $c r a c-$ civora (Fig. 3). The activity of PAL in 20- and 30-aphids infested leaves increased at the beginning, reached to the highest values at $48 \mathrm{hpi}$, then gradually fell within 48-96 hpi. However, PAL activity in the infested variants was always statistically higher than in the control $(\mathrm{p}<0.05)$, in which this enzyme remained at low levels and underwent minor changes throughout the experiments.

Cowpea aphid induced not only enzyme activity, but also expression of gene encoding PAL (PAL). Semiquantitative RT-PCR analysis indicated that $P A L$ began to express in $A$. craccivora-infested leaves $24 \mathrm{hpi}$, and maintained strong expression until $96 \mathrm{hpi}$ (Fig. 4A). The ratio intensity of $P A L$ and actin in the

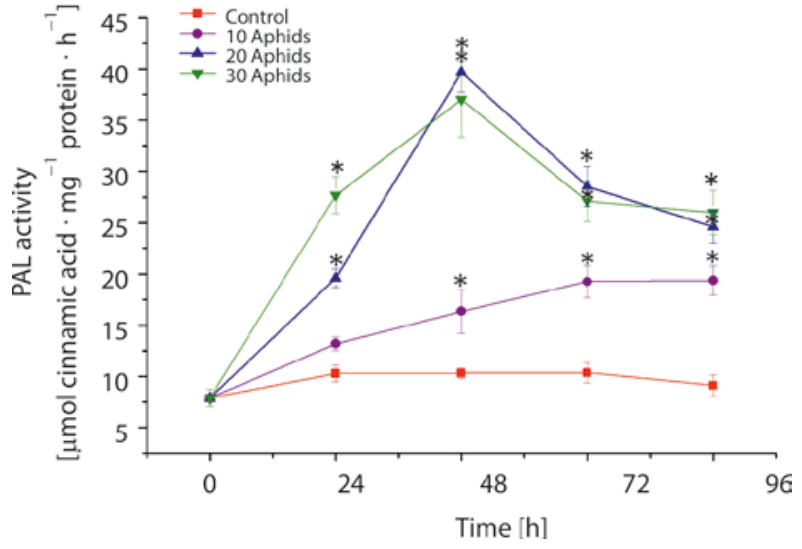

Fig. 3. Effect of Aphis craccivora infestation on activity of PAL in leaves of Glycine max cv. "Nam Dan". Values are means \pm SE of three independent experiments. $\left(^{*}\right)$ in figure shown the significant difference between the experimental variants and control at level $p<0.05$

infested leaves was always stronger than that in the control (Fig. 4C).

A

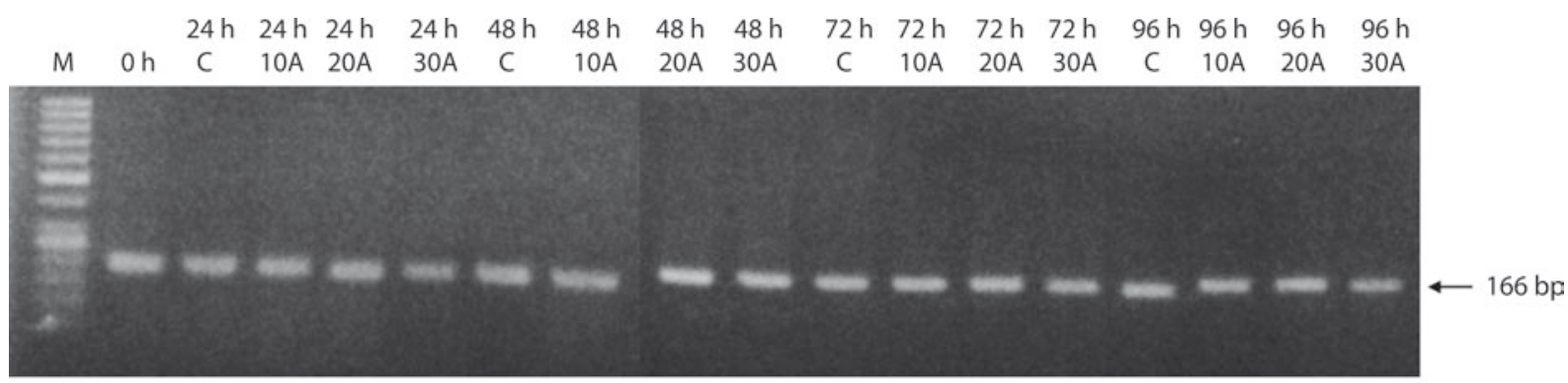

B
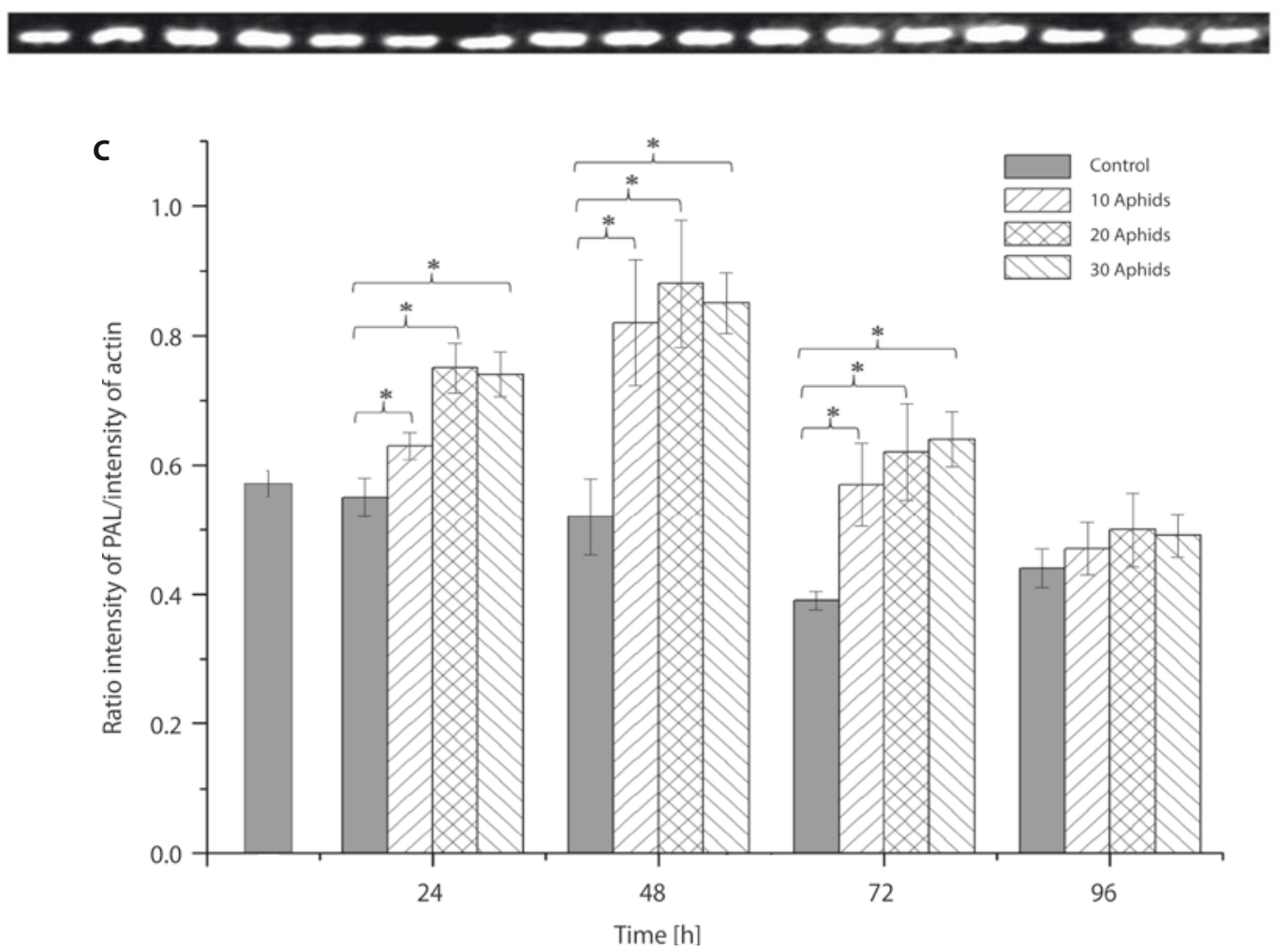

Fig. 4. Relative expression of $P A L$ gene in leaves of Glycine max cv. "Nam Dan" control and plants infested by Aphis craccivora (A), the constitutive expression actin (B) and a ratio intensity of PAL/intensity of actin $(C) .\left(^{*}\right)$ in figure shown the significant difference between the experimental variants and control at level $p<0.05$. $C$ - control, $A-$ aphids 


\section{Activity of BA2H in soybean leaves after aphid infestation}

BA2H activity in "Nam Dan" soybean leaves strongly accumulated $24 \mathrm{hpi}$ in all aphid-infested variants (Fig. 5). The highest value of BA2H activity (18.37 ng $\mathrm{SA} \cdot \mathrm{h}^{-1} \cdot \mathrm{mg}^{-1}$ protein) was detected in leaves infested by 30 aphids at 24 hpi. It was 3.44 -fold higher than that at the beginning, and 2.63-fold higher than the control plants. Benzoic acid 2-hydroxylase activity in aphidinfested leaves tended to decrease as the experimental time progressed, whereas this enzyme in the control changed little at low levels. The differences in $\mathrm{BA} 2 \mathrm{H}$ activity between the aphid-infested plants and the control were recorded at all investigated time points $(\mathrm{p}<0.05)$.

\section{Activity of LOX in soybean leaves after aphid infestation}

Infestation by $A$. craccivora caused an enhancement in LOX activity and expression of LOX isoform in soybean. Lipoxygenase activity in the aphid-infested

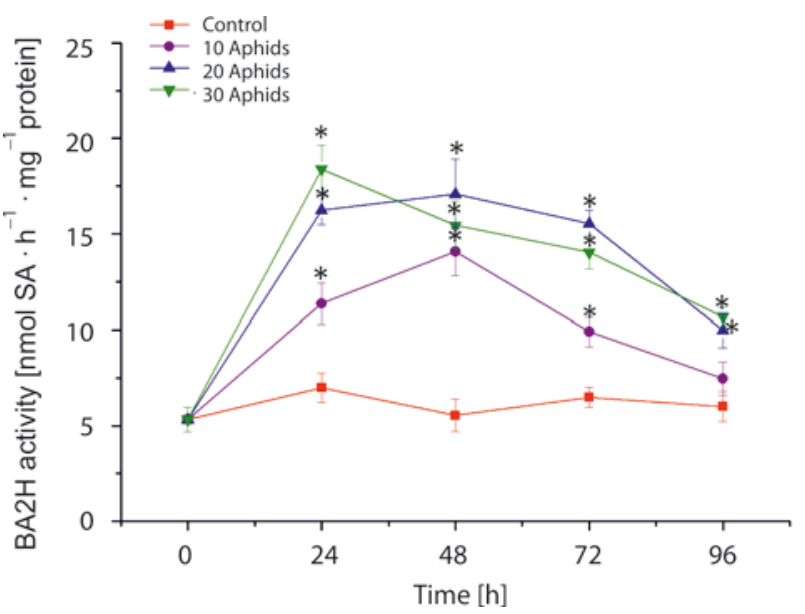

Fig. 5. Effect of Aphis craccivora infestation on activity of $\mathrm{BA} 2 \mathrm{H}$ in leaves of Glycine max cv. "Nam Dan". Values are means $\pm \mathrm{SE}$ of three independent experiments. $\left({ }^{*}\right)$ in figure shown the significant difference between the experimental variants and control at level $p<0.05$ leaves increased from the beginning to $96 \mathrm{hpi}$, and was higher than that observed in the control 48 hpi (Fig. 6). The significant differences between the infested variants and the control were recorded within 48-96 hpi $(\mathrm{p}<0.05)$. The variation of LOX activity was recorded with respect to aphid density and duration of infestation. Results from electrophoresis analyses recorded the presence of a LOX isoform in soybean leaves (Fig. 7). Interestingly, the intensity of that isoform increased throughout the experiment, which was similar to the change in LOX activity.

\section{Discussion}

\section{The SA signaling pathway in plant response to aphids}

Previous studies on various plant-aphid interactions have shown that endogenous SA was strongly accumulated to higher levels in response of resistant cultivars to aphids (Mohase and van der Westhuizen 2002;

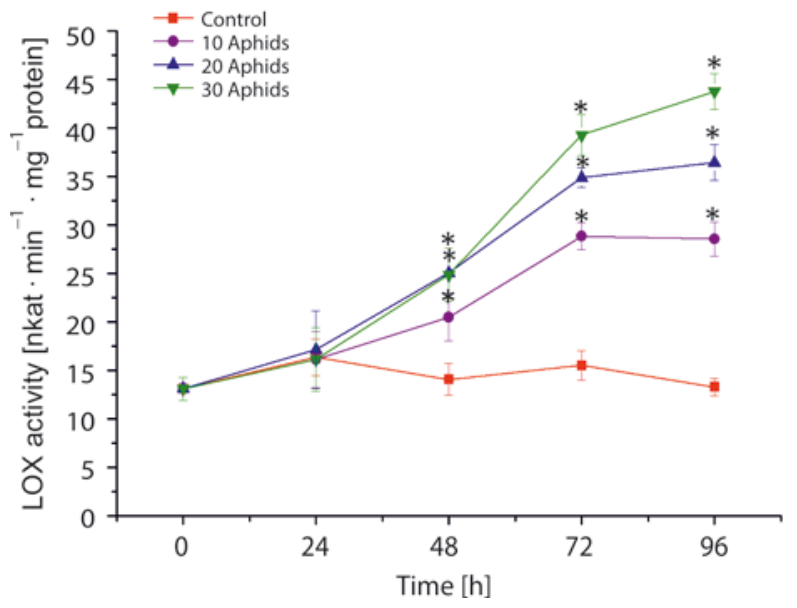

Fig. 6. Effect of Aphis craccivora infestation on activity of LOX in leaves of Glycine max cv. "Nam Dan". Values are means \pm SE of three independent experiments. $\left(^{*}\right)$ in figure shown the significant difference between the experimental variants and control at level $p<0.05$

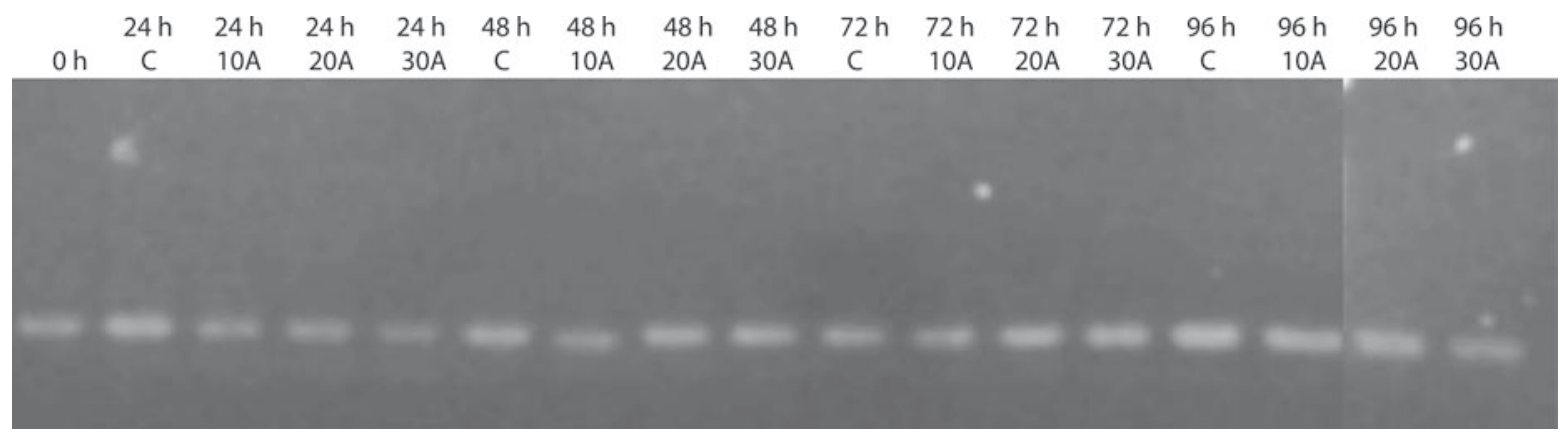

Fig. 7. Native gels staining for LOX isoenzymes in leaves of Glycine max cv. "Nam Dan” control and seedlings infested by Aphis craccivora. C - control, A - aphids 
Stewart et al. 2016) and the SA concentration increased following the time of aphid attack (Mohase and van der Westhuizen 2002). Our present study agreed with these reports as infestation by cowpea aphid induced dramatic increases of SA in the infested G. $\max \mathrm{cv}$. "Nam Dan" leaves (Fig. 2). The accumulated generation of SA is often associated with a build-up of reactive oxygen species that cause significant changes in cellular redox levels. These redox changes are sensed in the cytosol by the key defense gene NPR1 (NONEXPRESSOR OF PR1) - a vital component of SA signaling pathway (Monaghan et al. 2009). NPR1 involved in systemic acquired resistance (SAR), could influence plant defense against aphids via triggering expression of pathogenesis-related $(P R)$ genes responses (Moran and Thompson 2001). Significantly more PRs were induced within 12-24 h after aphid attack, suggesting that an early time period is required to develop the SA-related responses. In addition, a wide range of plant defenses against aphids depending on SA-signaling was involved in the induction of the transcription factors of the WRKY family (Kuśnierczyk et al. 2008). The simultaneous feeding of only a few aphids could induce the expression of gene WRKY70 (Kroes et al. 2015). These results supplied an important link between SA-signaling and different defense mechanisms in plants. Because early infestation of aphids invoked SA-defense genes, the strong accumulation of phytohormone SA may be a critical step in the signaling of downstream responses of plants to aphids.

Phenylalanine ammonia-lyase (PAL, EC 4.3.1.24) is the first enzyme in the SA biosynthesis pathway. An increase in PAL activity markedly affected the synthesis of the secondary metabolites, which led to biosynthesis of SA, flavonoids, isoflavonoid, and other antioxidants. Those compounds with deterrent, toxic and anti-nutritional properties were the aphid repellents that may prevent aphids from feeding or settling on hosts (Moran and Thompson 2001; Martinez de Ilarduya et al. 2003; Voelckel et al. 2004; Zhu-Salzman et al. 2004; Gao et al. 2007). In "Nam Dan" soybean plants, cowpea aphid induced not only enzyme activity, but also expression of gene $P A L$. This gene began to express in A. craccivora-infested leaves $24 \mathrm{hpi}$, and maintained strong expression until $96 \mathrm{hpi}$ (Fig. 4a). The feeding of a large number of cowpea aphids enhanced a high expression of enzyme and gene PAL in G. $\max \mathrm{cv}$. "Nam Dan" leaves.

Benzoic acid 2-hydroxylase (BA2H), whose major biochemical function is catalyzing the conversion of benzoic acid to SA, is directly related to SA signaling. To date, there is little information available about the involvement of $\mathrm{BA} 2 \mathrm{H}$ in plant response to herbivores. We previously observed an accumulation of $\mathrm{BA} 2 \mathrm{H}$ in the defense response of Pisum sativum to pea aphid (Mai et al. 2014). The present study revealed a strongly accumulated increase in activity of BA2H in "Nam Dan" soybean leaves infested by of cowpea (Fig. 5). Similar to PAL, the inducible change in BA2H activity was especially appropriated with the alteration of SA content, therefore, $\mathrm{BA} 2 \mathrm{H}$ probably participated in the SA-signaling pathway.

A proportional correlation between the activities of PAL and BA2H and the SA content in the aphid-infested leaves indicated that the enhancement of those enzymes is strongly associated with the accumulation of phytohormone SA in the SA-related defense pathway induced upon aphid infestation. It should be stressed that the change in SA content and PAL and BA2H activity were recorded with respect to the density of aphid infestation. A high-density of aphid attack (e.g., 20 or 30 cowpea aphid individuals per soybean plant) caused strong induction of the SA level and activity of PAL and $\mathrm{BA} 2 \mathrm{H}$ in the infested leaves of "Nam Dan" soybean.

\section{The JA signaling pathway in plant responses to aphids}

Jasmonic acid exerts its protective functions by regulating the expression of both direct and indirect defenses against herbivores (War et al. 2011). In the direct defense, via the basic helix-loop-helix transcription factor MYC2, JA enhances flavonoid biosynthesis, leading to a synthesis of defense compounds such as indole glucosinolates which serve as general poison and deterrent for herbivores (Fujita et al. 2009). The expression of MYC2 was significantly higher in plants simultaneously attacked by a high density of aphids (Kroes et al. 2015). Jasmonic acid also affects calciumdependent protein kinase $(C D P K)$ transcripts, which play an important role in plant defense against various stresses through signal transduction (Ulloa et al. 2002). In soybean plants, almost all GmCDPKs regulated plant wound- and herbivore-elicited defense responses were independent of JA signaling (Hettenhausen et al. 2016). In addition, JA played a role in indirect defense against insect pests through the induction of oxidative enzymes, proteinase inhibitors, alkaloids, and volatile compounds (War et al. 2011). Because of their potential roles in the synthesis of defense compounds and/or in oxidative stress tolerance, JA and related compounds are being implicated in plant resistance against insect herbivory. Jasmonic acid is also known to send important signals in the wounding response of plants. During feeding, aphid stylets penetrate plant tissues and result in cell damage such as disturbance of cell walls or disruption of plasma membranes (Tjallingii 2006). Jasmonic acid and its derivates directly promote the formation of COI1-JAZ complexes - the specific components of the "signal signature" that evoke a specific response to wounding (Katsir et al. 2008). 
As the key enzyme in the JA biosynthesis pathway, the participation of LOX in plant defense mechanisms against herbivorous insects has been demonstrated. First, LOXs are involved in the inducible herbivore resistance, which has been implicated in the direct plant defense via accumulation of oxidative enzymes and protease inhibitors (PIs, Bruinsma et al. 2010). Protease inhibitors inhibit the protease activity of the digestive enzymes in insects' guts; therefore, the insects become weak with stunted growth and ultimately die. Moreover, LOXs can catalyze the hydroperoxidation of linoleic and linolenic acids and form free radicals (e.g., superoxide anion, hydroxyl radicals), which may directly damage insect tissues, indirectly impair insect growth through damage to essential nutrients, and/or act as feeding repellents (Chamulitrat et al. 1991). Second, LOXs are involved in the indirect plant defense by release of herbivore-induced plant volatiles (HIPVs). The major signal transduction regarding HIPVs underlying insect-induced plant defenses is the octadecanoid pathway, from which, JA, MeJA, and OPDA can travel by air to nearby plants and attract the natural enemies of insect pests or affect herbivore behavior (Bruinsma et al. 2010).

In the "Nam Dan" soybean-cowpea aphid interaction, the content of phytohormone JA and the activity of enzyme LOX in the aphid-infested variants continuously increased according to the feeding duration. A large cowpea aphid attack induced a high expression of JA and LOX. It can be suggested that the JA-signaling pathway is important for the naturally derived aphid resistance trait of soybean "Nam Dan"; the change in expression of the defense-related compounds JA and LOX was strongly correlated with density and challenge duration of A. craccivora.

\section{Relationship between SA- and JA-signaling pathways}

In soybean leaves infested by cowpea aphid, the interaction between SA and JA was variously expressed at different intervals. In the early response, the SA-signaling pathway was strongly induced up-regulation, and probably dominated the expression of JA-signals. Salicylic acid and enzymes such as PAL and BA2H were enzyme LOX was kept in low expression within 24-48 hpi. In contrast, in the later responses (within 72-96 hpi), the high accumulated levels of JA and LOX in the JA-signaling pathway seem to depress the expression of elements in the SA biosynthetic pathway. The different enhancement of the SA- and JA-signaling pathways may contribute to a coordinated regulation leading to the specific defense responses, which improved the soybean resistance to cowpea aphid.

\section{Conclusions}

Infestation by cowpea aphid elicited the SA- and JAsignaling pathways in soybean leaves. An early induction of SA probably triggers the inducible specific defense reactions in the early response of soybean. An accumulation of JA in the later response may be a critical step in the signaling of down-stream defense in soybean "Nam Dan" to cowpea aphid. Being also induced by aphid infestation, enzymes PAL and BA2H in the SA biosynthetic pathway, enzymes LOX involved the biosynthesis of JA may strengthen the phytohormonal defense barriers in soybean "Nam Dan" during cowpea aphid attack process. The increases in the accumulated content of SA, JA and their biosynthetic enzymes are associated with G. $\max$ cv. "Nam Dan" resistance, and closely connected with density and infestation duration by cowpea aphid.

\section{Acknowledgements}

This research was funded by the Vietnam National Foundation for Science and Technology Development (NAFOSTED) under grant number: 106-NN.03-2014.22.

\section{References}

Bradford M. 1976. A rapid and sensitive method for the quantification of microgram quantities of protein utilizing the principle of protein-dye binding. Analytical Biochemistry 72 (1-2): 248-254. DOI: https://doi.org/10.1016/00032697(76)90527-3

Bruinsma M., van Broekhoven S., Poelman E.H., Posthumus M.A., Müller M.J., van Loon J.J.A., Dicke M. 2010. Inhibition of lipoxygenase affects induction of both direct and indirect plant defenses against herbivorous insects. Oecologia 162 (2): 393-404. DOI: 10.1007/s00442-009-1459-x

Cahill D.M., McComb J.A. 1992. A comparison of changes in phenylalanine ammonia-lyase activity. Lignin and phenolic synthesis in the roots of Eucalyptus calophylla (field resistant) and E. marginata (susceptible) when infected with Phytophthora cinnamoni. Physiological and Molecular Plant Pathology 40 (5): 315-332. DOI: 10.1016/0885-5765(92)90014-M

Chamulitrat W., Hughes M.F., Eling T.E., Mason R.P. 1991. Superoxide and peroxyl radical generation from the reduction of polyunsaturated fatty acid hydroperoxides by soybean lipoxygenase. Archives of Biochemistry and Biophysics 290 (1): 153-159. DOI: 10.1016/0003-9861(91)90601-E

Donovan M.P., Nabity P.D., DeLucia E.H. 2013. Salicylic acidmediated reductions in yield in Nicotiana attenuata challenged by aphid herbivory. Arthropod-Plant Interactions 7: 45-52. DOI: 10.1007/s11829-012-9220-5

Fan X., Mattheis J.P., Fellman J.K. 1998. A role for jasmonates in climacteric fruit ripening. Planta 204: 444-449. DOI: 10.1007/s004250050278

Fujita Y., Fujita M., Yamaguchi-Shinozaki K., Shinozaki K. 2009. Transcription factors involved in the crosstalk between abiotic and biotic stress-signaling networks. p. 43-58. In: "Signal Crosstalk in Plant Stress Responses" (K. Yoshioka, K. Shinozaki, eds.). Wiley Blackwell, 224 pp.

Gao L.L., Anderson J.P., Klingler J.P., Nair R.M., Edwards O.R., Singh K.B. 2007. Involvement of the octadecanoid path- 
way in bluegreen aphid resistance in Medicago truncatula. Molecular Plant-Microbe Interactions 20 (1): 82-93. DOI: 10.1094/MPMI-20-0082

Halitschke R., Baldwin I.T. 2005. Jasmonates and related compounds in plant-insect interactions. Journal of Plant Growth Regulation 23 (3): 238-245. DOI: 10.1007/s00344004-0037-z

Hettenhausen C., Sun G., He Y., Zhuang H., Sun T., Qi J., $\mathrm{Wu}$ J.2016. Genome-wide identification of calcium-dependent protein kinases in soybean and analyses of their transcriptional responses to insect herbivory and drought stress. Scientific Reports 6: e18973. DOI: 10.1038/srep18973

Katsir L., Chung H.S., Koo A.J.K., Howe G.A. 2008. Jasmonate signaling: a conserved mechanism of hormone sensing. Current Opinion in Plant Biology 11 (4): 428-435. DOI: 10.1016/j.pbi.2008.05.004

Kuśnierczyk A., Winge P., Jørstad T.M., Troczyńska J., Rossiter J.T., Bones A.M. 2008. Towards global understanding of plant defence against aphids-timing and dynamics of early Arabidopsis defence responses to cabbage aphid (Brevicoryne brassicae) attack. Plant, Cell \& Environment 31 (8): 1097-1115. DOI: 10.1111/j.1365-3040.2008.01823.x

Kroes A., Van Loon J.J.A., Dicke M. 2015. Density-dependent interference of aphids with caterpillar-induced defenses in Arabidopsis: involvement of phytohormones and transcription factors. Plant Cell Physiology 56 (1): 98-106. DOI: $10.1093 / \mathrm{pcp} / \mathrm{pcu} 150$

León J., Shulaev V., Yalpani N., Lawton M.A., Raskin I. 1995 Benzoic acid 2-hydroxylase, a soluble oxygenase from tobacco, catalyzes salicylic acid biosynthesis. Proceedings of the National Academy of Sciences 92 (22): 10413-10417.

Mai V.C., Drzewiecka K., Jeleń H., Narożna D., Rucińska-Sobkowiak R., Kęsy J., Floryszak-Wieczorek J., Gabryśs B., Morkunas I. 2014. Differential induction of Pisum sativum defense signaling molecules in response to pea aphid infestation. Plant Science 221-222: 1-12. DOI: 10.1016/j. plantsci.2014.01.011

Mai V.C., Tran N.T., Nguyen D.S. 2016. The involvement of peroxidases in soybean seedlings' defense against infestation of cowpea aphid. Arthropod-Plant Interaction 10 (4): 283-292. DOI: 10.1007/s11829-016-9424-1.

Martinez de Ilarduya O., Xie Q.G., Kaloshian I. 2003. Aphidinduced defense responses in $\mathrm{Mi}$-1-mediated compatible and incompatible tomato interactions. Molecular PlantMicrobe Interactions 16 (8): 699-708. DOI: 10.1094/ MPMI.2003.16.8.699
Mohase L., van der Westhuizen A. 2002. Salicylic acid is involved in resistance responses in the Russian wheat aphid-wheat interaction. Journal of Plant Physiology 159 (6): 585-590. DOI: 10.1078/0176-1617-0633

Monaghan J., Weihmann T., Li X. 2009. Plant innate immunity. p. 119-136. In: "Signaling and Communication in Plants" (F. Baluska, ed.). Springer-Verlag, Berlin Heidelberg, 308 pp.

Moran P.J., Thompson G.A. 2001. Molecular responses to aphid feeding in Arabidopsis in relation to plant defense pathways. Plant Physiology 125: 1074-1085. DOI: 10.1104/ pp.125.2.1074

Morkunas I., Mai V.C., Gabryś B. 2011. Phytohormonal signaling in plant responses to aphid feeding. Acta Physiologiae Plantarum 33 (6): 2057-2073. DOI: 10.1007/s11738-0110751-7

Rucińska R., Gwóźdź E.A. 2005. Influence of lead on membrane permeability and lipoxygenase activity in lupine roots. Biologia Plantarum 49 (4): 617-619. DOI: 10.1007/s10535-005-0059-9

Sekhar B.P.S., Reddy G.M. 1982. Studies on lipoxygenase from rice (Oryza sativa L.). Journal of the Science of Food and Agriculture 33 (11): 1160-1163. DOI: 10.1002/jsfa. 2740331114

Stewart S.A., Hodge S., Bennett M., Mansfield J.W., Powell G. 2016. Aphid induction of phytohormones in Medicago truncatula is dependent upon time post-infestation, aphid density and the genotypes of both plant and insect. Arthropod-Plant Interaction 10 (1): 41-53. DOI: 10.1007/s11829$-015-9406-8$

Tjallingii W.F. 2006. Salivary secretions by aphids interacting with proteins of phloem wound responses. Journal of Experimental Botany 57 (4): 739-745. DOI: 10.1093/jxb/erj088

Ulloa R.M., Raíces M., MacIntosh G.C., Maldonado S., TéllezIñón M.T. 2002. Jasmonic acid affects plant morphology and calcium-dependent protein kinase expression and activity in Solanum tuberosum. Physiologia Plantarum 115 (3): 417-427. DOI: 10.1034/j.1399-3054.2002.1150312.x

War A.R., Paulraj M.G., War M.Y., Ignacimuthu S. 2011. Jasmonic acid-mediated induced resistance in groundnut (Arachis hypogaea L.) against Helicoverpa armigera (Hübner) (Lepidoptera: Noctuidae). Journal of Plant Growth Regulation 30 (4): 512-523. DOI: 10.1007/s00344-011-9213-0

Yalpani N., Leon J., Lawton M.A., Raskin I. 1993. Pathway of salicylic acid biosynthesis in healthy and virus-inoculated tobacco. Plant Physiology 103 (2): 315-321. DOI: 10.1104/ pp.103.2.315 